\title{
The Role of Specialized Civil Society in Challenge Corruption with Glance to I.R.I
}

\author{
AmirNezam Barati \\ Department of Law, Imam Khomeini Maritime University, Nowshahr, Iran \\ E-mail: nezambarati@gmail.com
}

Mohsen Sharifi

Department of Law, Tabarestan University, Iran

E-mail: mohsen.sharifi181@gmail.com

Mohammad Hossain Nemati

Department of Management, Imam Khomeini Maritime University, Nowshahr, Iran

E-mail: comisser20@gmail.com

Farzad Karimi Birgani

Department of Management, Imam Khomeini Maritime University, Nowshahr, Iran

E-mail: farzadkarimi68@gmail.com

Received: June 5, 2017 Accepted: August 14, 2017 Online published: August 28, 2017

doi:10.5296/jpag.v7i3.11762 URL: https://doi.org/10.5296/jpag.v7i3.11762

\begin{abstract}
Combating against corruption is one of the most important factors for establishing Good Governance. Corruption is a social, political and economic phenomenon that defect the democratic institutions and stop establishing good governance.

This study using analytical - descriptive, analyses the role of civil society in combat corruption with glance to I.R.I
\end{abstract}




\section{MlMacrothink}

Journal of Public Administration and Governance

ISSN 2161-7104

2017, Vol. 7, No. 3

Findings of this study show that the role of special civil societies has remarkable efficiency and effectiveness in combat corruption. In challenging corruption different actor such as government, private sector and specialized civil society have function, but the role of civil societies is more effective than others.

In relating to the I.R.I actions against corruption, the country enacted different laws such as the law of access to information, the Law of United Nations Convention against Corruption and this process will send a clear message that the country is determined to prevent and control corruption.

In pathology of corruption in I.R of Iran the concentration on fighting against corruption, is concentrated on "The Staff of Combat against Economic Corruption" and civil society don't have effective or remarkable role to fight against this abnormality and this Staff is most important centers to harmonize the actions against corruption. Finally, the most important causes of corruption in every developing Nations in Transit such as Iran are big government and interference of Government in economy, the weakly embedded rule of law, the ineffective and inefficient of government policy, lack of accountability and institutional transparency.

Keywords: civil society, combat corruption, UN convention against corruption

\section{Introduction}

Corruption is an insidious plague that has a wide range of corrosive effects on societies. It undermines democracy and the rule of law, leads to violations of human rights, distorts markets, erodes the quality of life and allows organized crime, terrorism and other threats to human security to flourish. This evil phenomenon is found in all countries - big and small, rich and poor - but it is in the developing world that its effects are most destructive (Annan, 2003, p. iii). Corruption hurts the poor disproportionately by diverting funds intended for development, undermining a Government's ability to provide basic services, feeding inequality and injustice and discouraging foreign aid and investment. Corruption is a key element in economic underperformance and a major obstacle to poverty alleviation and development (Kofi A. Annan, 2004, p. iii).

One of the most important obstacles of development is corruption. Corruption is a complex phenomenon and Its roots lie deep in bureaucratic and political institutions, and its effect on development varies with country conditions (World Bank Group, 2015). Corruption Threat the national and international security and increase poverty.

The struggle with corruption is inevitable for I.R. I and as follow The Order of eight Article

Supreme leader of I.R. of Iran, "The Staff of Combat Against Economic Corruption " established in Monday, April 30, 2001 ( The Staff of Unison Against Economic Corruption, 2015). This staff is a combination of members of 3 branches of powers: The executive; The Judiciary, and Legislature.

${ }^{1}$ Setad Markazie Mobareze Ba Mafased Egtesadi 
In pathology of corruption in I.R.I the fighting against corruption is concentrated on mentioned staff and civil society don't have effective or remarkable role to fight against this abnormality. This article seeks to answer the questions as follows:

What are the costs of corruption?

How civil society can play an effective role in combat against corruption?

What are the roles of Especial civil society in Combating corruption in I.R.I ?

What are The main causes of corruption in I.R. of Iran?

To answer those questions, this paper will analyze cost of corruption (section 1), the role of civil society in compact corruption(section 2),

glance look to the role of Especial civil society in Combating corruption in I.R.I(section 3), The main causes of corruption in I.R. of Iran I(section 4).

\section{Definition of Corruption and Background}

Several definitions of 'corruption' have been proposed within national and international organizations. According to Oxford Dictionary, corruption is Dishonest or fraudulent conduct by those in power, typically involving bribery (Oxford Dictionaries, 2015). World Bank Group define corruption as "the abuse of public office for private gain (World Bank Group, 2015) in another definition Corruption is defined as exercise of official powers against public interest (Shah A. , 2006, p. 2). International Transparency as international civil organization defines Corruption as "the abuse of entrusted power for private gain. It can be classified as grand, petty and political, depending on the amounts of money lost and the sector where it occurs (International Transparency, 2016). In all definition the common subject is break of laws and regulation, dishonest or illegal behavior especially by powerful people (such as government officials or police officers) (merriam-webster, ...).

The cooperation between government and especial civil societies 2 is important and cooperation between the civil sector and government consider as a major prerequisite for successful anti-corruption reforms (Anti-corruption reforms in Bulgaria).

Geo-Sung Kim classified different role for The Role of Civil Society in the Fight against Corruption as Watchdog, identification of corruption-prone areas within the legal and administrative system, Raising Public Awareness, Civil Participation in decision-making processes to enhance transparency and fairness (Geo-Sung Kim, 2009). What is less clear in the literature of combat against corruption is the precise mechanism by which civil society fosters accountability and discourages corruption. Klitgaard offered this synthetic formula (Klitgaard, R., 2000):

Corruption $=\mathrm{m}$ (monopoly power $)+\mathrm{d}$ (discretion by officials $)-\mathrm{a}$ (accountability)

\footnotetext{
${ }^{2}$ The special civil society organization is NGO which the most important of its duty is combat against corruption.
} 
As the three concepts offered here are so interrelated, this formula describes a state of equilibrium rather than a causal model: corruption is high when discretion is high and accountability is low. We presume that the contribution of civil society is in the domain of increasing accountability. But as we also know that corruption results from the equilibrium between two general categories, resources and constraints we can try enriching this formula. Under resources we should consider the following categories documented in literature (Lejla Saduku, 2010, pp. 7-8):

- Power discretion (due not only to monopoly, but also privileged access under power arrangements other than monopoly)

- Material resources (public budget, foreign aid, natural resources, state assets, public sector employment)

Under constraints we should consider the following:

- Legal - This supposes an autonomous and effective judiciary able to enforce legislation.

- Normative -This implies that existing societal norms endorse ethical universalism and sanction deviation from this norm (through public opinion, media, civil society, voters)

Societal corruption is then the sum of the interaction which can be summarized in the formula below:

Corruption $=\mathrm{R}(\mathrm{Pd}+\mathrm{Mr})-\mathrm{C}(\mathrm{L}+\mathrm{Ce})$

Civil society then contributes directly to control of corruption by its capacity or lack of it - to inflict normative costs. For social accountability to work and civil society to be an effective actor, four elements need to coincide in a given society;

- A prevailing norm of honesty and integrity in a given society, civic capital

- A customary practice of engaging in formal or informal collective action around shared interests, purposes and values, social capital;

- A network of voluntary associations (among which NGOs in the Western understanding of the term), civil society.

- A sustained participation and political engagement on behalf of civil society, civic culture. According to Every mentioned research civil society has effective role in fighting against corruption that will be consider in following sections.

\section{Costs of Corruption}

According to the International Transparency ,Corruption impacts societies in a multitude of ways. This international NGO divided the cost of corruption into four main categories such as political, economic, social and environmental as follow (Transparency International, 2015):

\subsection{On the Political Front}

On the political effects, corruption is a major obstacle to democracy and the rule of law. In a 
democratic system, offices and institutions lose their legitimacy when they're misused for private advantage. This is harmful in established democracies, but even more so in newly emerging ones. It is extremely challenging to develop accountable political leadership in a corrupt climate.

\subsection{Economical Effects}

Economically, corruption depletes national wealth. Corrupt politicians invest scarce public resources in projects that will line their pockets rather than benefit communities, and priorities high-profile projects such as dams, power plants, pipelines and refineries over less spectacular but more urgent infrastructure projects such as schools, hospitals and roads. Corruption also hinders the development of fair market structures and distorts competition, which in turn deters investment. According to the assessment of world Bank the international cost of corruption is $1000,000,000 \$$ every year (WorldBank, 2006, p. 171).

\subsection{Corruption Corrodes the Social Fabric of Society}

It undermines people's trust in the political system, in its institutions and its leadership. A distrustful or apathetic public can then become yet another hurdle to challenging corruption.

\subsection{Environmental Degradation}

Environmental degradation is another consequence of corrupt systems. The lack of, or non-enforcement of, environmental regulations and legislation means that precious natural resources are carelessly exploited, and entire ecological systems are ravaged. From mining, to logging, to carbon offsets, companies across the globe continue to pay bribes in return for unrestricted destruction.

\subsection{Costs of Corruption According to the World Bank Experience}

The following expressions emerge of the many ways in which corruption imposes costs as follows:

\subsubsection{Undermining Macroeconomic Stability}

Macroeconomic stability may be undermined by loss of government revenue and excessive spending. This can happen through corruption in tax and customs departments, through debt incurred when the scrutiny of finance ministries and central banks is bypassed, through contracts that are awarded to high-cost bidders or without competitive tendering, and through the general erosion of expenditure control.

\subsubsection{Effect in Decreasing Foreign Direct Investment}

Even so, corruption can have a negative effect on foreign investment. Where corruption is large and systemic, investment may be concentrated in extractive industries in which operations can be enclave, or in light manufacturing or trading operations that can be relocated if corruption costs become unbearable. Or foreign investors may shun the country altogether. For most foreign firms, corruption is a cost of doing business to be recouped from revenues. ${ }^{17}$ If the costs become too high or unpredictable, foreign firms will disengage unless 
global marketing or sourcing considerations require them to maintain a presence in that country. High levels of corruption add to the risk of a country being marginalized in the international economy.

\subsubsection{Effect on Small Entrepreneurs}

Small entrepreneurs may be affected in many developing and transition economies. Evidence from private sector assessments suggests that corruption increases the costs of doing business, that small firms bear a disproportionately large share of these costs, and that bribes can prevent firms from growing (Susan Rose-Ackerman and Andrew Stone).

A survey of 3,600 firms in 69 countries carried out for the 1997 World Development Report provides further evidence of the widespread existence and negative effects of corruption. As noted in the report: The survey confirmed that corruption was an important - and widespread - problem for investors. Overall, more than 40 percent of entrepreneurs reported having to pay bribes to get things done as a matter of course. . . Further, more The consequences of corruption often do not end with paying off officials and getting on with business. Government arbitrariness entangles firms in a web of time-consuming and economically unproductive relations. The survey also confirms the negative correlation between the level of corruption (as perceived by businesspeople) and the level of investment in an economy ( World Bank, 1997).

\section{The Role of Effective Participation of the SCSOs in Fight against Corruption}

The "Specialized Civil Societies Organization" ${ }^{3}$ has a key role in fighting against corruption, from monitoring public services, denouncing bribery to raising awareness of all economic and political actors. Since most cases of corruption involve pubic officials and private companies, civil society as an independent actor representing the interests of the general public is uniquely positioned denounce and expose corruption cases and put pressure for reform. Governments, therefore have to take measures to enable and strengthen civil society participation and civil society has to be aware of its role and make use of its potential leverage (OECD,CleanGovbiz, 2013, p. 3). An effective and positive participation of the civil society in the battle with corruption depends on three key factors as follows (OECD,CleanGovbiz, 2013, p. 3):

1. The existence of a legal framework that enables Civil Society Organizations' (CSOs) participation without political and legal restrictions.

2. The willingness of the state to engage constructively with the civil society and

3. The effective engagement of CSOs in the fight against corruption.

In other view point participation of the civil society in the fight against corruption depends on other key factors as follows

${ }^{3}$ SCSOs are nonprofit and nongovernmental organization that main duties' are combat against corruption. 
1). There should be legal provisions that aim at respecting and protecting the freedom of citizens and CSOs to seek, receive and publish information regarding corruption and these provisions must be clear and unambiguous.

2). Citizens and CSOs should be informed about the government's anti-corruption work and bodies, their role, agenda and actions and the information should be easily accessible especially on the internet.

3). Citizens and CSOs should be consulted and actively participating in the decision-making and policy-making processes by government.

4). Citizens should have the right to propose new legislation and they participating in working groups for draft the law.

In addition, Geo-Sung Kim classified different role for effective the role of civil society in the fight against corruption as follows: Watchdog that exposes corruption cases and criticizes corrupt officials and institutions, including judiciary. Civil societies can identify corruption-prone areas within the legal and administrative system. This identification is not less important than that of public authorities or private sector, because of its different sources and different perspectives. Additionally, Raising Public Awareness is one of advantages of civil society. These NGOs makes efforts to rise "public awareness regarding the existence, causes and gravity of and the threat posed by corruption," as UNCAC ${ }^{4}$ article 13 says. It publicizes some indices, reports, and study results for better awareness on the issue. Some CSOs operate information centers like $\mathrm{ALAC}^{5}$, as well as education centers for that purpose. In addition civil society Participation in decision-making processes can contribute to enhance transparency and fairness. Some CSOs are operating networks for preparing a sufficient human resource for civil participation through e-education, training and networking activities. Constructing reservoir for civil participation, in other words, making Civil Participation Infrastructure, is very much needed for more active participation in the future (Geo-Sung Kim, 2009).

Active Public Involvement in the Fight against Corruption is inevitable. The fight against corruption cannot be won without citizens' support, participation and vigilance. The media, civic and business associations, trade unions and other nongovernmental actors play a crucial role in fostering public discussion of corruption and increasing awareness about the negative impacts of corruption (ADB/OECD, 2015, pp. 57-63). The Medias, civil and commercial associations and other NGOs have effective role in forming and exchange the point of view of people to fight against corruption. The experience of developing and developed countries show that recognizing the role of NGOs in combating corruption is one of the most effective toll in combating corruption (hamdami Ghotbeh Saraie, 2008, p. 245). Therefore

\footnotetext{
${ }^{4}$ United Nations Convention against Corruption

${ }^{5}$ Advocacy and Legal Advice Centers
} 
participation of Special Civil Societies in detection and stoppage of corruption and harmony of the activities of SCOs with government are activities that SCOs can do to fight against corruption (Secretary-General of theOECD, 2003).

In addition there are two main approaches to fighting corruption: the top-down approach and the bottom-up approach (civil society approach).The top-down approach has to do with developing and naturalizing new rules, institutions, and norms that target the "public administrative graft." The primary weakness of this approach, however, is that the very institutions accused of corruption are responsible for enacting change. Those benefiting from corruption are much less likely to end it than those suffering from corruption, but the importance of the bottom-up approach, which requires the mobilization of ordinary citizens don't need complex starch. A large, united public outcry provides the force of change that reformed infrastructure alone can't (New Tactics, 2010).From the other viewpoint there are two basic factors that CSOs can do their role to minimize corruption and be fruitful to do this mission:

1- Freedom of peaceful assembly and of association

2- Access to information make excellent situation to minimize corruption opinion of government about cooperation with CSOs should be open and fruitful and the government should develop a constructive cooperation with CSOs.

A key part of the process of empowerment is access to information. Citizens who access to information and informed of the corruption within their political systems are able to fight against corruption more effectively as well as develop their own strategies to do so. It is also extremely important to educate people about their rights, especially those who have limited access to such information, such as those living in remoteness and poverty.

\subsection{Public Scrutiny and Access to Information}

CSOs should raising awareness against corruption and monitoring the actions and decisions of governments in potential risk areas, they also exposing corruption cases and criticizing corrupt officials and institutions.

CSOs actively promoting civil society's participation and building coalitions with key stakeholders in order to influence the public policy debate and they should be able for lobbying and proposing alternatives for new institutional devices and solutions to prevent or penalize corruption.

In addition one of the key role the public plays in the fight against corruption is to monitor and scrutinize actors and hold them accountable. This scrutiny is a powerful means to prevent corruption and a key supplement to legal provisions and institutions. Its two preconditions free discussion and access to related information (ABD/OECD, 2004, p. 36) -, however, are not sufficiently given in some countries like Iran.

If information is a tool for power the access to this power make civil societies to be enabling in supervise the act of government. A particularly important precondition to enabling citizens to scrutinize the public administration, government, political parties and elected politicians is 
a meaningful right to access to information and this right goes beyond routine publication of documents; effective control additionally requires that governmental or administrative institutions disclose files for scrutiny upon request (ADB/OECD , 2003, p. 37).

\section{The Study of Civil Society Role in Combat Corruption in I.R of Iran}

In spite of the fact that, the combat against corruption is propagated but the special civil societies don't established yet and they don't have any role in fighting against corruption and the only actor is governmental organizations. The formal Statistics show that the vast number of corruption cases shows that corruption is increasing in I.R. I. and combat against corruption is more a election motto (Rabiei, 2012) and civil societies don't have any role in this combat and the most concentration is on government institutes. International Transparency that considered the occurrence of corruption in the world in 2016, classified the score of countries from zero( high corrupt) to one hundred ( most transparent).This organization in its report studied 177 countries that shows Corruption Perceptions Index in every part of world. The rank of Iran is 131 from 176 and its score is 29 from 100 . According to the report of this international civil society, Control of Corruption in Iran (2010) is about $20 \%$ (International Transparency, 2016).

In the discussion about Cause Analysis of corruption in Iran we can tell that there is no special academic center to study about corruption. Unlike to the mottos and hubbubs there is no consensus against corruption in the condition that corruption id a social, economical, cultural, political and even security in Iran. There are no formal courses at education centers such as university in the country. There is no remarkable Research about the causes and consequences of corruption and fight against corruption is not scientific and the number of research is not remarkable. The remarkable fact is that the study of cause of corruption is limited by security center of organizations as if corruption is the red line of research and it means that the preparation about the study of the subject is not exist yet. The lack of special civil society as a supervisor in government decision making process is a great weak and there is no sign of it in fight against corruption (Rabiei, 2012).

The most important factor for extension of corruption is governmental economy and big government and until 2015 more than $70 \%$ of Iran economy is governmental and this kind of economy model had not been effective in any part of the world (Eslamian, 2013). The government of Japan with 130 million populations has 339,785 Employee but I.R.I has more than 3488985 in its public and government sectors.

The size of private sector is about $30 \%$ and this process shows that private sector don't have effective role in economy and it cause amplitude or bigness of government is the most important reason for financial and political corruption

\section{The Main Causes of Corruption in I.R. of Iran}

The main causes of corruption in I.R. of Iran are Big government, The weakly rule of law, lack of accountability, The inefficient commitment of national administrators, that identified by different studies classified as follow: 


\subsection{Big Government of I.R. of Iran}

The extensive size of government and its interference in the economy of the country are the most important reasons of fanatical and administrative corruption. These days the role of the state in economy is more than $\% 70$ percent and big industries in I.R. of Iran are governmental. According to the Article 44 of constitutional law of the Islamic Republic of Iran, the economy of the Islamic Republic of Iran is to consist of three sectors: the state, the cooperative, and the private sector as follows:

1). The state sector is to include all large-scale and mother industries, foreign trade, major minerals, banking, insurance, power generation, dams and large-scale irrigation networks, radio and television, post, telegraph and telephone services, aviation, shipping, roads, railroads and the like; all these will be publicly owned and administered by the State.

2). The cooperative sector is to include cooperative companies and enterprises concerned with production and distribution, in urban and rural areas, in accordance with Islamic criteria.

3). The private sector consists of those activities concerned with agriculture, animal husbandry, industry, trade, and services that supplement the economic activities of the state and cooperative sectors. Ownership in each of these three sectors is protected by the laws of the Islamic Republic, in so far as this ownership is in conformity with the other articles of this chapter, does not go beyond the bounds of Islamic law, contributes to the economic growth and progress of the country, and does not harm society. The [precise] scope of each of these sectors, as well as the regulations and conditions governing their operation, will be specified by law.

\subsection{The Rule of Law is Weakly Embedded}

Public sector corruption thrives where laws apply to some but not to others, and where enforcement of the law is often used as a device for furthering private interests rather than protecting the public interest (AnwarShah, 2004, p. 43) according to international transparency the enforcement of the law in I.R of Iran is \%20 in South Korea \%81 and Philippine \%35 (Transparency International, 2010)

\subsection{The Commitment of Government in Combat Corruption is Weak}

Widespread corruption endures in the public sector when national authorities are either unwilling or unable to address it forcefully. In societies where public sector corruption is endemic, it is reasonable to suspect that it touches the highest levels of government, and that many senior office holders will not be motivated to work against it (Anwar Shah and Mark Schacter,, 2004, p. 41).

\subsection{Accountability and Institutional Transparency are Insufficient}

In societies where the level of public sector corruption is relatively low, one normally finds strong institutions of accountability and transparency that control abuses of power by public officials. These institutions are either created by the state itself (for example, auditors-general, the judiciary, the legislature) or arise outside of formal state structures (for example, the news 
media and organized civic groups) Widespread corruption endures in the public sector when national authorities are either unwilling or unable to address it forcefully. In societies where public sector corruption is endemic, it is reasonable to suspect that it touches the highest levels of government, and that many senior office holders will not be motivated to work against it. (Anwar Shah and Mark Schacter,, 2004, p. 41). There are glaring weaknesses in institutions of accountability in highly corrupt countries like Iran.

\section{Conclusion}

In this paper, I looked at the role of Especial civil society in Combating corruption with glance to I.R.I

In modern world, the scope of economic activity and fiscal Interaction is extensive and complex that supervision without civil society is one of main reasons of corruption. The fight against corruption should do by every actor of society such as government, private sector, and civil society. The mentioned actors can play their role in cooperation with each other, but between them, the role of civil society is more effective and crucial in this struggle. And I reaffirm the importance of core values such as honesty, respect for the rule of law, accountability and transparency in combat corruption in every mentioned sector.

The I.R.I enacted different laws such as the law of access to information, the Law of United Nations Convention against Corruption and..., will send a clear message that the country is determined to prevent and control corruption.

At present The Staff of Combat against Economic Corruption that (combination of members of 3 branches of powers, the executive, Judiciary; and Legislature) is the centers to harmonize the actions against corruption. In pathology of corruption in I.R of Iran the concentration on fighting against corruption is concentrated on mentioned staff and civil society don't have effective or remarkable role to fight against this abnormality.

In addition in Iran, especial civil societies are in the beginning of the path to tackle corruption or this kind of NGO is not established until now, while the parliament ratified the law of UN Convention against corruption and it is necessary to execute and recognize the role of these NGOs in this hard struggle.

Finally, in Iran the Special Civil Society are in the begging of their mission and there is no Special Civil Society for fighting against corruption and governmental organizations ,in the general meaning, is the only responsible to struggle with corruption. It seems that "Iran special civil society has long way to start fighting against corruption", therefore the role of civil societies should be revised. In fact, unlike the laws that ratified in the parliament of I.R. of Iran there is no special civil society against corruption and these kind of societies don't have considerable role in the battle against corruption.

\section{Suggestions}

4 Suggestions for minimizing corruption in the mention countries and developing countries presented as follows: 
1). Citizen empowerment in fight against corruption

This could be done through support for bottom-up reforms. In many countries where corruption is entrenched, governments lack either the will or the capability to mount effective anticorruption programs. External development partners may choose to amplify citizens' voice and strengthen exit mechanisms so as to enhance transparency, accountability, and the rule of law.

2). Dissemination of Information

Access to the information of government operations is a powerful antidote to corruption. More influence donors can exert on strengthening citizens' right to know and on governments to release timely, complete, and accurate information about government operations, the better the prospects for reducing corruption. Information about how governments spend money and manage programs, and about what these programs deliver in services to people, is a key ingredient of accountability, which in turn may be an important brake on corruption.

3). Economic policy reform and private sector

In I.R. of Iran the government role in economy is more than $\% 70$ therefore minimizing government role in trade and financial liberalization and real privatization can reduce opportunities for corruption by limiting the situations where officials might exercise unaccountable discretionary powers.

4). Involvement of other stakeholders such as civil society

As I expressed, In I.R. of Iran, it is important to engage other national stakeholders such as civil society, people and private sector in the fight against corruption. Participatory processes of civil society, people and private sector are very effective method in challenging corruption.

\section{Acknowledgement}

The research is financed by Imam Khomeini Maritime University. Thanks for Dr. Mohammad Hossein Zarei the National University, Faculty of Law.

\section{References}

ABD/OECD. (2004). Anti-Corruption Policies In Asia and Pacific available. OECD Available at,www.oecd.org.

ADB/OECD. (2003). Active Public Involvement ,Public Scrutiny and Access to Information,Anti-Corruption Initiative for Asia and the Pacific. OECD.

ADB/OECD. (2015). ADB/OECD Anti-Corruption Initiative for Asia and the Pacific,Active Public Involvement in the Fight against Corruption. Manila, Philippines: Published by the Asian Development Bank.

Ampratwum, E. F. (2008). The fight against corruption and its implications for development in developing and transition economies. Journal of Money Laundering Control, 11(1), 76-87. https://doi.org/10.1108/13685200810844514 
Anti-corruption reforms in Bulgaria. Available at:www.csd.bg/files/5en.pdf.

Anwar S., \& Mark, S. ( 2004). Combating Corruption:Look Before You Leap. Finance \& Development , 41.

Anwarshah, S. M. (2004). Combating Corruption: Look Before You Leap, A lack of progress in eradicating corruption could be due to misguided strategies ,. World Bank, finance and development department.

Baygzadeh, E. (2014). The role of civil society in combat against corruption. THE Conference of UN in combat Against Corruption Association for UN Studies (p. Http://www.iauns.org/internal_news/detailpage/Fa/). Teharan: Iranian Association for UN Studies .

Burger, E. S. (2006). Why the private sector is likely to lead the next stage in the global fight against corruption.

Business-Anti-Corruption Patrol. (2015). The United Nations Convention against Corruption. Retrieved

from http://www.business-anti-corruption.com/about/about-corruption/united-nations-convention-a gainst-corruption.aspx.

Center For The studyof Democracy. (2005). Anti corruption Reforms in Bulgaria, civil society against corruption.

Eigen, P. (2002). Measuring and combating corruption. The Journal of Policy Reform , pp. 187-201. https://doi.org/10.1080/1384128032000096805

ESCAP, U. (2006). What is good governance?. United Nations. Economic and Social Commission for Asia and the. Pacific. Available at www.unescap.org.

Eslamian, M. (2013, August 28). The cause of corruption. Retrieved September 2, 2015, from http://iccima.ir/fa/.

Fitzwilliam, E. F. (2008). The fight against corruption and its implications for development in developing and transition economies. Journal of Money Laundering Control, 11(1), 76-87. https://doi.org/10.1108/13685200810844514

Fitzwilliam, E. F. (2o11). The fight against corruption and its implications for development in developing and transition economies,. Journal of Money Laundering Control, University of Cambridge, Cambridge, UK, , 1.

Geo, S. K. (2009). The Role of Civil Society in the Fight Against Corruption. 8th regional seminar: corruption prevention. Macao SAR, P. R. China: https://www.oecd.org/site/adboecdanti-corruptioninitiative/meetingsandconferences/4287729 2.pdf.

Hamdami, G. S. A. (2008). Finacial Corruption Cause, consequence and The Stratgies To Fight Against it. Tehran: Ferdusi Publication. 
Http://www.unodc.org/unodc/en/corruption/. (210). UNODC's Action against Corruption and Economic Crime.

Huguette Labelle. (15 February2012). A Speech bout The Role of Civil Society in the Fight Against Corruption. The Role of Civil Society in the Fight Against Corruption . Santo Domingo,, Dominican Republic.

International Transparency. (2016). Iran report. Available at http://www.transparency.org/country/\#IRN.

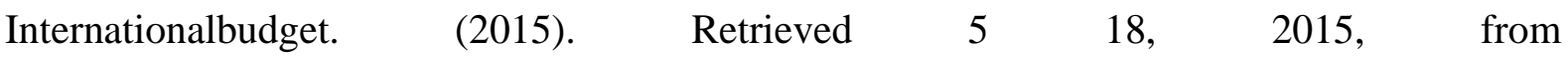
http://internationalbudget.org/groups/concerned-citizens-of-abra-for-good-government-ccagg/ Jooyoung, K., \& Joongi, K. (2001). Shareholder Activism in Korea: A Review of How PSPD Has Used Legal Measures to Strengthen Korean Corporate Governancet. Journal of Korean Law, 53.

Klitgaard, R. (2000). Controlling Corruption,. California: Berkeley, University of California Press.

Kofi, A. A. (2004). United Nations Convention against Corruption,Foreword,enacted by General Assembly, General Assembly resolution 58/4 of 31 October 200. New York : United Nations Office on Drugs and Crime.

Lejla, S. A. P. (2010). The Experience of Civil Society as an Anticorruption Actor in East Central Europe. Romania: Romanian Academic Society and Hertie School of Governance.

Merriam-webster. (...). Corruption. Retrieved 1 20, 2017, from merriam-webster: http://www.merriam-webster.com/dictionary/corruption

New Tactics. (2010, August 31). Empowering Citizens to Fight Corruption. Retrieved 620 , 2016, from https://www.newtactics.org/conversation/empowering-citizens-fight-corruption: https://www.newtactics.org/conversation/empowering-citizens-fight-corruption

OECD, A. (2001). Anti-Corruption Initiative for Asia and the Pacific ,Active Public Involvement in the Fight against Corruption. ADB/OECD. ADB/OECD.

OECD,cleangovbiz. (2013). Civil society empowerment. (OECD) Retrieved june 2015, 2015, from http://www.oecd.org/cleangovbiz/civilsocietyempowermentdraft.pdf.

OECD. (2003). Fighting Corruption What Role For Civil Society? The Experience of The OECD. Paris : OECD.

OECD. (2013, April ). Civil society empowerment. Retrieved August 11, 2015, from http://www.oecd.org/cleangovbiz/civilsocietyempowermentdraft.pdf.

$\begin{array}{llll}\text { Oxford } & \text { Dictionaries. } & \text { (2015). } & \text { Retrieved }\end{array}$ http://www.oxforddictionaries.com/definition/english/corruption.

Pacific, U. N. (2014). Accountability cannot be enforced without transparency and the rule of law. Www.unescap.org/pdd. 
Rabiei, A. (2012, September 2). Interview about sociology of corruption . (M. A. Behzad, Interviewer).

Rightlivelihood. (2003). Citizens' Coalition for Economic Justice, CCEJ (2003, South Korea). Retrieved 5 10, 2015, from http://www.rightlivelihood.org/ccej.html.

Robert, K., \& Heather, B. (1997). Working together to fight corruption : state, society and the private sector in partnership, Originally published in: Governance Innovations: Lessons from Experience, Building Government-Citizen-Business Partnerships,Suzanne Taschereau and Jose Edgardo L.

Secretary-General of theoecd. (2003). Fighting Corruption What Role For Civil Society? The Experience Of The OECD. OECD.

Shah, A. (2006). Corruption and Decentralized Public Governance. World Bank Policy Research Working Paper 3824, 2.

Shah, A. A. (2004). Combating corruption: look before you leap. Finance and Development, 41(4), 40-43.

The central Staff of Challenge Against Economic Corruption. (2015). Economic Corruption. Retrieved 5 25, 2015, from http://ww.nezarat.gov.ir/.

The Staff of Unison Against Economic Corruption. (2015). Economic Corruption. Retrieved 5 25, 2015, from http://ww.nezarat.gov.ir/.

Transparency International. (2010). Corruption by Country / Territory. Retrieved 2015, from https://www.transparency.org/country/\#PHL.

Transparency International. (2015). WHAT ARE THE COSTS OF CORRUPTION. Retrieved 2015, from http://www.transparency.org/what-is-corruption/\#costs-of-corruption.

UNODC. (2014). UNODC's Action against Corruption and Economic Crime, available athttp://www.unodc.org/unodc/en/corruption/. UNODC.

Unodc. (2104). United Nations Economic and Social Commission, What is Good Governance?,. Available at www.unescap.org.

Vinay Bhargava, Emil Bolongaita. (2004). Challenging Corruption in Asia. Washington, D.C.: / The World Ba.

Vitotanzi, H. D. (1997). Corruption, Public Investment, and Growth. IMF Working Paper97/139, p. 4.

Wikileaks. (2015). Concerned Citizens of Abra for Good Government (CCAGG). Retrieved 8 25, 2015, from https://wikileaks.org/wiki/Concerned_Citizens_of_Abra_for_Good_Government_\%28CCAG G\%29.

World Bank Group. (2015). Helping Countries Combat Corruption: The Role of the World Bank. Retrieved 6 17, 2015, from Worldbank: 


\section{Macrothink}

Journal of Public Administration and Governance

ISSN 2161-7104 2017, Vol. 7, No. 3

http://www1.worldbank.org/publicsector/anticorrupt/corruptn/cor02.htm

World Bank. ( 1997). World Development Report : The State in a Changing World. New York: Oxford University Press.

World Bank. (2014). Helping Countries Combat Corruption: The Role of the World Bank. Http://www1.worldbank.org/publicsector/anticorrupt/corruptn/corrptn.pdf.

You, J. S. (2003). The Role of Civil Society in Combating Corruption in Korea. 11th International Anti-Corruption Conference,, (pp. 1-11). Seoul, Korea,.

Zibakalam, S. ( 2015, May 28). The cause of corruption is dominance of government in economy . Retrieved July 4, 2015, from https://www.tabnak.ir/fa/news/504073.

\section{Copyright Disclaimer}

Copyright for this article is retained by the author(s), with first publication rights granted to the journal.

This is an open-access article distributed under the terms and conditions of the Creative Commons Attribution license (http://creativecommons.org/licenses/by/4.0/). 